\title{
Prothrombine and activated partial thromboplastin time are prolonged in hepatic cirrhosis
}

\author{
Edward Kurnia Setiawan Limijadi*, Lisyani Budipradigdo Suromo*, \\ and Imam Budiwiyono*
}

\begin{tabular}{l}
\hline \\
\hline *Department of Clinical Pathology, \\
Faculty of Medicine, \\
Diponegoro University, Semarang \\
Correspondence \\
Edward Kurnia Setiawan Limijadi \\
Department of Clinical Pathology, \\
Faculty of Medicine, \\
Diponegoro University \\
Jl. Dr Sutomo No. 16-18 \\
Semarang 50244 \\
Mobile: +62838 6230 5904 \\
Email: liemsianhok@yahoo.com
\end{tabular}

Univ Med 2016;35:26-32

DOI: $10.18051 /$ UnivMed.2016.v35.26-74 pISSN: 1907-3062 / eISSN: 2407-2230

This open access article is distributed under a Creative Commons Attribution-Non Commercial-Share Alike 4.0 International License

\section{BACKGROUND}

Chronic hepatitis and hepatic cirrhosis are chronic liver diseases that cause disorders of liver function, such as the formation of platelets and coagulation factors (prothrombin time/PT and activated partial thromboplastin time/APTT). Chronic hepatitis in the long term can develop into hepatic cirrhosis. The aim of this study was to determine platelet count, PT, and APTT as indicators in the progression of chronic hepatitis towards hepatic cirrhosis.

\section{METHODS}

A cross-sectional study was conducted on 50 patients with chronic hepatitis and hepatic cirrhosis in Semarang City Regional General Hospital, Telogorejo Hospital and Kariadi General Hospital. The platelet count was measured with a Sysmex XP-100, while PT and APTT was measured with a Sysmex CA-1500 coagulometer. The Mann Whitney test was applied to analyze the difference in platelet count, PT, and APTT between chronic hepatitis and hepatic cirrhosis.

\section{RESULTS}

Median, minimum, and maximum values of platelet count, PT and APTT in chronic hepatitis were $284.000 / \mu \mathrm{l}, 210.000 / \mu \mathrm{l}, 390.000 / \mu \mathrm{l} ; 10.6 \mathrm{sec}$, $9.5 \mathrm{sec}, 13.6 \mathrm{sec}$; and $30.5 \mathrm{sec}, 24.2 \mathrm{sec}, 46.4 \mathrm{sec}$, respectively, and in hepatic cirrhosis they were $96.300 / \mu \mathrm{l}, 48.200 / \mu \mathrm{l}, 133.800 / \mu \mathrm{l} ; 27.5 \mathrm{sec}$, $11.9 \mathrm{sec}, 44.7 \mathrm{sec}$; and $55.6 \mathrm{sec}, 31.3 \mathrm{sec}, 72.0 \mathrm{sec}$, respectively. There was a significant difference the reduction of platelet count, and the prolongation of PT and APTT in chronic hepatitis compared to hepatic cirrhosis $(\mathrm{p}=0.000)$.

\section{CONCLUSIONS}

Prothrombine time and APTT were prolonged and platelet count was decreased in hepatic cirrhosis subjects. The three parameters may be used to evaluate the progression of chronic hepatitis towards hepatic cirrhosis.

Keywords: Platelet count, PT, APTT, chronic hepatitis, hepatic cirrhosis 


\section{INTRODUCTION}

Chronic liver disease comprises chronic hepatitis kronis and hepatic cirrhosis. ${ }^{(1)}$ With regard to hepatic cirrhosis, the morbidity and mortality rates have significantly increased in developing countries, particularly as a result of hepatitis viruses B and C. ${ }^{(2,3)}$ Anatomically, hepatic cirrhosis consists of extensive fibrosis with nodule formation in all parts of the liver, and not limited to one lobule. ${ }^{(4)}$

Chronic liver disease causes decreased liver function, and furthermore decreased thrombopoietin synthesis, leading to thrombocytopenia. Thrombocytopenia in chronic liver disease is also caused by platelet sequestration from portal hypertension and the suppression of platelet production in the bone marrow. ${ }^{(5)}$ Mihai et al. ${ }^{(6)}$ assert that chronic hepatitis $\mathrm{C}$ is associated with thrombocytopenia; the more severe the chronic hepatitis, the more severe the resulting thrombocytopenia. Sylvester et al. ${ }^{(7)}$ state that abnormalities of platelet count occur in liver disease associated with hepatitis virus B infection. In hepatic cirrhosis, the platelet count is lower than in chronic hepatitis.

The synthesis of coagulation factors that play a role in hemostasis will be reduced in chronic liver disease. Routine coagulation tests, i.e. simultaneous determination of protrombine time (PT) and activated partial thromboplastine time (APTT) are required to evaluate both procoagulant pathways. PT and APTT are prolonged in chronic liver disease. ${ }^{(8)}$ Tagwa et al. ${ }^{(9)}$ state that PT and APTT are prolonged in patients with hepatic cirrhosis, as compared with healthy persons, indicating the occurrence of abnormalities of hemostasis in these patients. ${ }^{(9)}$ Ahmadhameed et al. ${ }^{(10)}$ state that prolonged PT and APTT indicate lack of coagulation factors. Abnormalities of platelet count, PT, and APTT in chronic hepatitis have not been much studied previously. The purpose of present study was to determine the three above-mentioned parameters as indicators of the progression of chronic hepatitis towards hepatic cirrhosis.

\section{METHODS}

\section{Study design}

A cross-sectional study was conducted from March to May 2014 at the ambulatory clinic and hospital wards of Semarang City Regional General Hospital, Telogorejo Hospital and Kariadi General Hospital.

\section{Study subjects}

The sample size for each group was calculated from the formula of the difference of two means as follows ${ }^{(11)}$ :

$$
\mathrm{n}_{1}=\mathrm{n}_{2}=2\left[\frac{\left(\mathrm{Z}_{\alpha}+\mathrm{Z}_{\beta}\right.}{\left(\mu_{1}-\mu_{2}\right)}\right]^{2}
$$

At an effect size of $0.8, \mathrm{Z}_{\alpha}$ of 1.96 and $\mathrm{Z}_{\hat{\mathrm{a}}}$ of 0.84 , the sample size in each group was 25 .

Selection of the study subjects was performed by non-random consecutive sampling. Chronic hepatitis was diagnosed on the basis of HBsAg positive tests for more than 6 months in the case of chronic hepatitis B infection and on the basis of anti-HCV positive tests for more than 6 months in the case of chronic hepatitis C infection. Hepatic cirrhosis was diagnosed from the clinical picture, comprising the signs of liver cell failure, i.e. edema, jaundice, spider nevi, pectoral alopecia, gynecomastia, liver damage, ascites, loss of pubic hair, palmar erythema, and testicular atrophy in males, and the signs of portal hypertension, i.e splenomegaly, esophageal varices, caput medusae, ascites, and hemorrhoids. On USG examination of the abdomen, there are nodules, irregularities, increased echogenicity, and liver atrophy, with positive HBsAg and/or anti-HCV test results.

The respondents in this study were 21-60 years old; male and female; body temperature within normal limits (36.8-37.2 ${ }^{\mathrm{UC}}$ ); normal sleeping and resting pattern, normal eating and drinking pattern (not alcoholic); regular menstruation in females, and agreeing to participate in the study. Excluded from this study were patients on anticoagulants, dextran, isoniazide, quinidine, phenylbutazone; having a 
history of malignancies, joint disease, skin rash, hemophilia, anemia; menstruating females, and patients with lipemic and hemolyzed blood samples.

\section{Questionnaire}

One study questionnaire was handed out to each of the respondents, who were requested to fill it in completely. The questionnaire contained the respondent's identity, history of illness associated with chronic hepatitis and hepatic cirrhosis, and history of other illnesses. In case a questionnaire was not completely filled-in, the investigators completed it with data from the medical record and from an interview with the respondent.

\section{Laboratory examination}

Venous blood samples were collected from the respondents with chronic hepatitis and hepatic cirrhosis to determine the platelet count, PT, and APTT. The blood sample was collected from the median cubital vein to a volume of 5 $\mathrm{mL}$, drawn into a vacutainer tube containing $3.2 \%$ EDTA and sodium citrate, and then homogenized. Subsequently the blood sample was transported to the laboratory of Dr. Kariadi General Hospital, Semarang, for examination. The blood in the citrate tube was centrifuged at $3000 \mathrm{rpm}$ for 5 minutes. The platelet count, PT, and APTT were determined without delay, using a Sysmex XP-100 instrument and a Sysmex CA1500 coagulometer and corresponding reagents. The normal platelet count was taken as 150.000 $450.000 / \mu 1$, while the reference value of PT was 9.8-12.1 seconds and that of APTT was 26.437.5 seconds. ${ }^{(12)}$

\section{Statistical analysis}

The collected data were edited, coded, and entered into the required computer program. The difference in platelet count, PT, and APTT values between chronic hepatitis and hepatic cirrhosis was tested with the Mann-Whitney test, since the data were not normally distributed. The degree of significance used was 0.05 .

\section{Ethical clearance}

Written informed consent was obtained from all respondents in this study and the identity of the patients was kept secret. Permission to conduct the study was obtained from the Commission for Medical Research Ethics, Faculty of Medicine, Diponegoro University/Dr. Kariadi General Hospital, Semarang, under no. 609/EC/FK-RSDK/2014.

\section{RESULTS}

The median age of the chronic hepatitis patients was 47 years, with minimum and maximum values of 22 and 60 years, respectively, whereas the median age of the hepatic cirrhosis patients was 55 years, with minimum and maximum values of 35 and 60 years, respectively. Not all study subjects knew if they had been diagnosed as having chronic hepatitis and hepatic cirrhosis. The minimum and maximum values of the duration of hepatitis in the group with chronic hepatitis were 7 months and 252 months, respectively. The minimum and maximum values of the duration of hepatitis in the group with hepatic cirrhosis were 108 months and 168 months, respectively. The minimum and maximum values of the duration of hepatic cirrhosis were 3 months and 72 months, respectively (Table 1).

There were more males than females among the subjects with chronic hepatitis and hepatic cirrhosis. The number of males with chronic hepatitis was $76 \%$, which was higher than the number of females with chronic hepatitis, this being $24 \%$. The number of males with hepatic cirrhosis was $72 \%$, which was higher than the number of females with hepatic cirrhosis, namely $28 \%$.

The study results regarding the type of hepatitis are presented in Table 1, where it is apparent that the percentage of hepatitis B was $88 \%$ and that of hepatitis $\mathrm{C}$ was $12 \%$. The percentages of each type of hepatitis were identical between hepatic cirrhosis and chronic hepatitis groups. 
Table 1. Distribution of respondent characteristics by hepatitis status

\begin{tabular}{|c|c|c|}
\hline Characte ristic of respond ents & $\begin{array}{c}\text { Chronic hep atitis } \\
(n=25)\end{array}$ & $\begin{array}{c}\text { Hepatic cirrho sis } \\
(n=25)\end{array}$ \\
\hline \multicolumn{3}{|l|}{ Age (years) } \\
\hline Median & 47 & 55 \\
\hline Minimum-maxim um values & $22-60$ & $35-60$ \\
\hline \multicolumn{3}{|l|}{$\mathrm{G}$ ender (percent) } \\
\hline Male & 76 & 72 \\
\hline Female & 24 & 28 \\
\hline \multicolumn{3}{|l|}{ Duration of hepatitis (months) } \\
\hline Minimum-maxim um values & $7-252$ & $108-168$ \\
\hline \multicolumn{3}{|l|}{ Type of hepatitis virus (percent) } \\
\hline Hepatitis B & 88 & 88 \\
\hline Hepatitis C & 12 & 12 \\
\hline \multicolumn{3}{|l|}{ Duration of hepatic cirhosis (months) } \\
\hline Minimum-maximum values & - & $3-72$ \\
\hline
\end{tabular}

The platelet count in hepatic cirrhosis subjects was significantly reduced in comparison with the chronic hepatitis subjects. The prothrombine time and APTT were significantly prolonged in hepatic cirrhosis subjects in comparison with the chronic hepatitis subjects $(\mathrm{p}=0.000)($ Table 2).

\section{DISCUSSION}

The results of our study showed the median age of patients with chronic hepatitis and hepatic cirrhosis to be 47 and 55 years, respectively. Essentially similar results were obtained in the study by Sajjadieh et al, ${ }^{(13)}$ who found that the mean age of patients with chronic hepatitis was 44.8 years, and that of patients with hepatic cirrhosis was 43.2 years. Differing results were obtained in the studies by Elzouki et al. ${ }^{(14)}$ and Fawad et al. ${ }^{(15)}$ The present study is in agreement with the study of the Ministry of Health, Republic of Indonesia, showing that hepatitis has the highest prevalence of $1.4 \%$ in the age group of 45-54 years. ${ }^{(16)}$

The median age of the hepatic cirrhosis subjects disagrees with that of Daniel, who states that hepatic cirrhosis is more prevalent in the age group of 45-54 years. ${ }^{(17)}$ The Indonesian Liver Researchers Association (Perhimpunan Peneliti Hati Indonesia, PPHI) writes that the mean age of patients with hepatic cirrhosis is 44 years, which lies within the interval between the minimum and maximum. ${ }^{(18)}$ This study is similar to the study by Rahmat et al. ${ }^{(19)}$ who found that hepatic cirrhosis is more prevalent between the ages of 36 and 60 years.

Table 2. Differences in platelet count, PT and APTT between chronic hepatitis and hepatic cirrhosis

\begin{tabular}{lccc}
\hline \multirow{2}{*}{ Variable } & \multicolumn{2}{c}{ Median (minimum-maximum) } & \multirow{2}{*}{ p } \\
\cline { 2 - 3 } & Chronic hepatitis & Hep atic cirrhosis & $0.000^{*}$ \\
P1 atelet count $(\mu)$ & 284,000 & 96,300 & \\
PT (seconds) & $(210,000-390,000)$ & $(48,200-133,800)$ & $0.000^{*}$ \\
APTT (seconds) & 10.6 & 27.5 & \\
& $(9.5-13.6)$ & $(11.9-44.7)$ & $0.000^{*}$ \\
\hline
\end{tabular}

*: Statistical testing using the Mann-Whitney test 
In our study there were more males with chronic hepatitis than females. This situation agrees with the study by Elzouki et al. ${ }^{(14)}$ who state that the prevalence of hepatitis was higher in males than in females. The Ministry of Health of the Republic of Indonesia states that males have a higher hepatitis prevalence than females. ${ }^{(16)}$

In the present study, the number of male patients with hepatic cirrhosis was higher than that of female patients. This is in agreement with Ratib et al. ${ }^{(20)}$ who state that the prevalence of hepatic cirrhosis was higher in males than in females.

Infection with hepatitis B virus was more prevalent than that with hepatitis $C$ virus in the chronic hepatitis and hepatic cirrhosis groups. This is similar to that obtained by Kiah et al. ${ }^{(21)}$ and Marc et al., ${ }^{(22)}$ in that hepatitis B infection was more frequent than hepatitis $\mathrm{C}$ infection. This agrees with the report written by the National Institute for Health and Care Excellence (NICE), ${ }^{(23)}$ that chronic hepatitis B in its course will develop into hepatic cirrhosis and the report by Kenneth ${ }^{(24)}$ that patients with chronic hepatitis $\mathrm{C}$ will develop cirrhosis.

The platelet count is lower in hepatic cirrhosis than in chronic hepatitis. The difference in platelet count between chronic hepatitis and hepatic cirrhosis in our study is similar to that found in the study by Sylvester et al., ${ }^{(7)}$ namely that the platelet count in hepatic cirrhosis is significantly lower than in chronic hepatitis. Tagwa et al. ${ }^{(9)}$ writes that the platelet count in hepatic cirrhosis is significantly reduced, in comparison with the control group. Thrombocytopenia may occur in hepatic cirrhosis through several mechanisms, i.e. splanchnic sequestration, reduced activity of thrombopoetin (TPO), depression of bone marrow by chronic infection with hepatitis virus, interferon antiviral therapy, and autoantibodies against platelet surface antigens. ${ }^{(5,25)}$

Rafique et al. ${ }^{(26)}$ state that PT and APTT are significantly prolonged in hepatic cirrhosis, in comparison with chronic hepatitis, which is similar to our study results. Tagwa et al. ${ }^{(9)}$ also state that PT and APTT values in hepatic cirrhosis are significantly different from those in the chronic hepatitis group. Bikha et al. ${ }^{(27)}$ write that PT and APTT are significantly prolonged in patients with hepatic cirrhosis, in accordance with the severity of the disease.

The prothrombine time and APTT in hepatic cirrhosis may be prolonged as a result of several factors. Firstly, decreased factor VII followed by decreases in factors $\mathrm{V}$ and $\mathrm{X}$ and prothrombin. ${ }^{(28)}$ Vitamin K deficiency may occur, thus inhibiting the synthesis of factors VII, IX, and $X^{(29)}$

The differences in platelet count, PT, and APTT between chronic hepatitis and hepatic cirrhosis are caused by the severity of hepatic injury, which is different in both situations. Although there is abnormal liver function in chronic hepatitis, this function can still be compensated, since not all hepatic tissues are replaced by fibrous tissue. Hepatic cirrhosis differs from chronic hepatitis, since in hepatic cirrhosis the liver function cannot be compensated anymore, because there is a diminishing amount of hepatic tissue, while the majority has been replaced by fibrosis.

The significant differences in the three parameters between chronic hepatitis and hepatic cirrhosis can be used as the basis for evaluating the condition of the patients / for follow-up. We recommend that patients with chronic hepatitis, according to the instructions of the physician, undergo periodic determination of the three parameters for evaluation of the disease, so that the development of hepatitis into hepatic cirrhosis may be known at an earlier point in time. On the basis of our study results, if the platelet count starts to decrease, the patient has entered the hepatic cirrhosis state. The prolonged prothrombine time and APTT indicate that the patient is starting to enter the hepatic cirrhosis state.

One limitation of this study was that we did not perform a further evaluation of the exact timing of the decrease in platelet count, and the prolongation of PT and APTT, before the chronic 
hepatitis progresses to hepatic cirrhosis. Further studies on the three parameters using a cohort design may be conducted to evaluate the degree of severity of chronic hepatitis before progressing to hepatic cirrhosis, so that the exact timing of the change may be known.

\section{CONCLUSION}

Platelet count, PT and APTT may be used to evaluate the progress of chronic hepatitis to hepatic cirrhosis.

\section{CONFLICT OF INTEREST}

The investigators confirm that there was no conflict of interest.

\section{ACKNOWLEDGEMENT}

The investigators wish to thank the laboratory analysts and nurses at Dr. Kariadi General Hospital, Semarang, Telogorejo Hospital, Semarang, and Semarang City Regional General Hospital, who assisted in this study in the collection and examination of the samples.

\section{REFERENCES}

1. Ivanova L, Russev V. Chronic liver disease and parenterally transmitted hepatitis viruses. Eur J Inflamm 2007;5:1-6.

2. Ricardo R, Rui TM, Miguel S. Classification and staging of chronic liver disease from multimodal data. IEEE Trans Biomed Eng 2012;60:133644.

3. Guntur H. Perspektif masa depan imunologi infeksi. Surakarta: Sebelas Maret University Press; 2006.

4. Sherlock S, Dooley J, editors. Disease of the liver and biliary system. $11^{\text {th }}$ ed. USA: Blackwell Science; 2002.

5. Hiromitsu H, Toru B, Ken S, et al. Management of throombocytopenia due to liver cirhosis: A Riview. World J Gastroenterol 2014;20:2595605.

6. Olariu M, Olariu C, Olteanu D. Thrombocytopenia in chronic hepatitis C. J Gastrointestin Liver Dis 2010;19:381-5.
7. Sylvester CN, Obike I. Quantitative platelet abnormalities in patients with hepatitis B virusrelated liver disease. Gastroenterol Res 2009;2: 344-9.

8. Reverter JC. Abnormal hemostasis tests and bleeding in chronic liver disease: are they related? J Thromb Haemos 2006;4:717-20.

9. Tagwa YE, Fathelrahman MH. Assessment of platelets count and coagulation parameters among Sudanese patients with liver cirrhosis. RMJ 2013;38:215-8.

10. Ahmadhamed A, Samina N, Saeed S, et al. An assessment of coagulation parameters in liver cirrhosis. Biomedica 2006;22:74-7.

11. Dawson B, Trapp RG. Basic \& clinical biostatistics. $4^{\text {th }}$ ed. New York: Mc Graw-Hill; 2014.

12. Siemens. Thromborel S. Germany: Siemens 2008:1-2.

13. Sajjadieh M, Viunytska L. Prothrombin time in patients with and without fibrotic chronic liver disease. Int J Pathol 2008;8:1-5

14. Elzouki AN, Smeo MN, Sammud M, et al. Prevalence of hepatitis B and $C$ virus infections and their related risk factors in Libya: a national seroepidemiological survey. East Mediterr Health J 2013;19:589-99.

15. Fawad K, Sulaiman S, Ihteshamud DQ, et al. Hepatitis B virus infection among different sex and age groups in Pakistani Punjab. Virology J 2011;8:1-5.

16. Badan Penelitian dan Pengembangan Kesehatan Kementrian Kesehatan RI. Riset kesehatan dasar (Riskesdas) Kementrian Kesehatan RI. Jakarta: Badan Penelitian dan Pengembangan Kesehatan; 2013.

17. Daniel HC. Chronic liver disease and cirrhosis deaths in California. California: California Department of Health Services; 2006.

18. Perhimpunan Peneliti Hati Indonesia (PPHI). Sirosis hepatis; 2013.

19. Rahmat H, Ramli HA, Elvie L. Hubungan gambaran USG pada penderita sirosis hati dengan fibrosis skor di Bagian Radiologi RSUP Prof. Dr. R. D. Kandou Manado periode Januari 2013 - Desember 2013. E-Clinic; 2014;2:1-9.

20. Ratib S, West J, Crooks CJ, et al. Diagnosis of liver cirrhosis in England, a cohort study, 19982009: a comparison with cancer. Am J Gastroenterol 2014;109:190-8.

21. Kiah H, Syarif HD, Edhiwan P, et al. Penatalaksanaan hepatitis B kronik. Majour 2010;1:1-7.

22. Marc GG, Doris BS, David LT, et al. Hepatology: Diagnosis, management, and treatment of hepatitis C. An Update 2009;49:1335-74. 
23. National Institute for Health and Care Excellence (NICE). Hepatitis B chronic. United Kingdom: Health and Social Care Directorate; 2013.

24. Kenneth ES. Perspective advanced liver disease: what every hepatitis $C$ virus treater should know hepatitis. IAS-USA 2011;19:121-5.

25. Nezam A, John MH, Robert B, et al. Thrombocytopenia associated with chronic liver disease. J Hepatol 2008;48:1000-7.

26. Rafique AM, Badar A, Riaz AQ. The importance of abnormal coagulation tests and management of bleeding in chronic liver disease. MC 2011;17:65-8.

27. Bikha RD, Mir AAT, Aneela AR, et al. Coagulopathies in patients with liver cirrhosis. World Appl Sci J 2012;17:1-4.

28. Jody LK. Hemostatic defects in end stage liver disease. Crit Care Clin 2005;21:563-87.

29. Senzolo M, Burra P, Cholongitas E, et al. New insights into the coagulopathy of liver disease and liver transplantation. World J Gastroenterol 2006;12:7725-36. 